\title{
Quality comparison of hot-water leachate from teabags containing Citrus junos peels dried using different methods
}

\author{
Han-Sol Park ${ }^{1}$, Hyeon-Jeong Lee ${ }^{2}$, Kwang-Sup Youn ${ }^{3}$, Dong-Seob Kim ${ }^{1}$, \\ Han-Soo Kim $^{1}$, Young-Guen Lee ${ }^{1}$, Jong-Hwan Seong ${ }^{1}$, Hun-Sik Chung ${ }^{1 *}$ \\ ${ }^{1}$ Department of Food Science and Technology, Pusan National University, Miryang 50463, Korea \\ ${ }^{2}$ Department of Food Science and Biotechnology, Kyungpook National University, Daegu 41566, Korea \\ ${ }^{3}$ Department of Food Science and Technology, Catholic University of Daegu, Gyeongsan 38430, Korea
}

\section{건조방법을 달리한 유자껍질 티백차의 품질특성 비교}

\author{
박한솔 ${ }^{1} \cdot$ 이현정 ${ }^{2} \cdot$ 윤광섭 $^{3} \cdot$ 김동섭 $^{1} \cdot$ 김한수 $^{1} \cdot$ 이영 근 $^{1} \cdot$ 성종환 $^{1} \cdot$ 정헌식 $^{1 *}$ \\ ${ }^{1}$ 부산대학교 식품공학과, ${ }^{2}$ 경북대학교 식품공학부, ${ }^{3}$ 대구가톨릭대학교 식품공학전공
}

\begin{abstract}
This study was conducted to investigate the effects of drying methods for Citrus junos peels on quality characteristics of the hot-water leachate from teabags containing those peels. Fresh peels were hot-air $\left(50^{\circ} \mathrm{C}\right)$, cold-air $\left(30^{\circ} \mathrm{C}\right)$, or freeze-dried $\left(-45^{\circ} \mathrm{C}\right)$, powdered to a size of 40 mesh, packaged with a paper sachet, and then the packaged teabags were leached for $10 \mathrm{~min}$ with hot-water $\left(70^{\circ} \mathrm{C}\right) . \mathrm{L}^{*}$ value (lightness) and $-\mathrm{a}^{*}$ value (greenness) of the peel powder were the highest in the freeze-dried samples. Soluble solids and titratable acidity of the teabag leachate were in the following order; cold-air, freeze, and hot-air dried samples. Among free sugar contents in all samples, fructose content was the highest, followed by glucose and sucrose. Fructose and glucose contents were not affected by drying methods. There was no significant difference in the flavonoid content among the peels dried using three drying methods. DPPH radical-scavenging activity of the leachate was the highest in the cold-air dried sample. These results suggest that cold-air drying would be an effective method to enhance the quality of hot-water leachate of teabags prepared from $C$. junos peels.
\end{abstract}

Key words : Citrus junos, drying, teabags, leaching, peel

\section{서 론}

유자나무(Citrus junos)는 귤속 식물 중 내한성과 내병성 이 비교적 강한 상록관목이며 동아시아 지역이 원산지와 주재배지이고, 그 열매인 유자는 종자가 많고 특유취와 강 한 산미를 가져 생식 및 가공원료로서 한계가 있으며 주로 당절임차와 같은 제한된 형태로 소비된다(1). 그러나 최근 들어 유자가 가지는 면역력 증진효과(2), 미백효과(3), 항산

*Corresponding author. E-mail : hschung@pusan.ac.kr Phone : 82-55-350-5352, Fax : 82-55-350-5359

Received 9 November 2017; Revised 13 December 2017; Accepted 21 December 2017.

Copyright (c) The Korean Society of Food Preservation. All rights reserved.
화효과(4), 항비만효과(5), 항암효과(6) 및 항아토피효과(7) 등의 건강 기능성이 과학적으로 규명되면서 소비자의 관심 이 높아지고 있으며 생산자와 소비자 모두를 위한 신규 가공품의 개발과 고부가가치화가 필요한 실정이다.

유자의 구성은 껍질, 육질, 종실 등으로 크게 나눌 수 있는데, 이들 중 껍질은 두껍고 표면이 울퉁불퉁하며 전체 과실의 약 40-45\% 정도를 차지하고 향기성분, 섬유소, 플라 보노이드 등이 비교적 많이 함유되어 있다(8-10). 이러한 유자껍질의 활용성 증대를 위한 연구로는 올레오레진, 소 시지, 쿠키, 진양주, 막걸리 등의 제조(11-15)에 관한 것이 수행된 바 있으며, 또한 유자껍질 열수추출물이 강한 항산 화능을 가지는 것으로 밝혀져 이의 음용차 원료로서 높은 가치를 인정받았다(4). 음용차는 약용 및 기호성 식물체로 부터 유효성분을 섭취하기 위한 수단으로 원료를 건조한 
후 열수에 우리거나 타서 마시는 식품형태이다(16). 동일한 원료의 음용차 품질은 제조공정, 침출 및 음용방법 등에 의해 결정되는 것으로 알려져 있으며(17), 제조공정 중 건조 방법으로는 천일건조, 열풍건조, 냉풍건조, 동결건조 등이 있고, 침출 및 음용방법으로는 열수, 가압, 초음파를 이용한 방법과 건조원료의 형상과 포장상태 등이 있다(18-20). 건 조방법 중 열풍건조는 가장 일반적인 방법이나 다른 인공건 조법들 보다 품질손실이 큰 것으로 알려져 있고, 냉풍건조 는 열풍건조보다 건조속도가 느리지만 화학성분의 변화가 적으며, 동결건조는 동결상태에서 수분을 승화시키는 것이 원리이며 건조에 따른 품질변화가 비교적 적지만 비용이 높은 것으로 평가되고 있다(21). 상기한 방법과 기술들이 다양한 음용차 원료 제조에 적용되고 있지만 품목마다 반응 이 다르므로 특정 품목에 대한 적용에 앞서 효과 검정이 선행되어야 한다. 그러나 유자껍질의 음용차 원료 제조에 있어 건조방법과 티백 포장에 따른 이화학적 품질특성에 관한 연구는 미흡한 실정이다.

따라서 본 연구에서는 유자껍질을 활용한 고품질 음용차 원료를 제조하기 위한 공정설정의 일환으로, 건조방법에 따른 분말 티백의 열수침출 음용차의 품질 특성을 조사하고 적합한 건조방법을 결정하고자 하였다.

\section{재료 및 방법}

재 료

실험용 유자 과실은 2016년 11월 15일 경상남도 남해군 에서 수확한 '남해재래' 품종을 익일 배송 받아 크기와 표면 색도가 균일한 과실을 선별하고 껍질과 육질을 분리한 후 껍질만을 사용하였다. 이때 과실 한 개당 평균 무게는 162 $\mathrm{g}$ 이었고 이 중 껍질이 차지하는 비율은 약 $42 \%$ 이었다.

\section{건조 및 티백포장 방법}

유자껍질을 8 등분하고 열풍건조, 냉풍건조 및 동결건조 를 각각 실시하였다. 즉, 열풍건조는 cabinet-type 열풍건조 기(JSOF-150, JSR Co., Gongju, Korea)를 이용하여 $50^{\circ} \mathrm{C}$ 에 서 행하였고, 냉풍건조는 냉풍건조기(JJ-1000, Chunjin $\mathrm{E} \& \mathrm{C}$ Co., Gyeongsan, Korea)를 이용하여 $30^{\circ} \mathrm{C}$ 에서 행하였 으며, 동결건조는 진공동결건조기(FD SFDSM12, Samwon, Seoul, Korea)로 $-45^{\circ} \mathrm{C}$ 에서 행하였다. 건조한 유자껍질은 분쇄기를 사용하여 $0.351 \mathrm{~mm}$ 이하로 분쇄하여 분말(수분 함량 약 $11 \%$ )을 얻고, 이들 $2 \mathrm{~g}$ 씩을 삼면무지 자동포장기 (Kukdong Machinery Co., Seoul, Korea)로 만든 paper sachet $(70 \mathrm{~mm} \times 40 \mathrm{~mm}$, Heat-sealable Filter Paper, Ahlstrom, Windsor Locks, CT, USA)에 충전하고 열접착 밀봉하여 티 백을 제조하고 이를 침출용 시료로 사용하였다.
티백 침출 음용차 제조

유자껍질 티백 한 개를 유리 비커에 담고 여기에 $70^{\circ} \mathrm{C}$ 증류수 $100 \mathrm{~mL}$ 를 붓고 $25^{\circ} \mathrm{C}$ 항온기에서 10 분간 침출한 후 티백을 제거하고 여과지(No.2, ADVANTEC, Tokyo, Japan)로 여과하여 음용차 시료를 얻고 냉장 보관하면서 이화학적 특성을 분석하였다. 이때 침출 온도와 시간은 전 보(22)와 예비실험을 통하여 설정하였다.

\section{색도 측정}

신선 유자껍질과 건조분말의 색도는 colorimeter(CR400, Konika Minolta Inc., Tokyo, Japan)를 사용하여 CIE L*, a*, $\mathrm{b}^{\star}, \mathrm{h}^{\circ}, \mathrm{C}^{\star}$ 값을 각각 측정하였다. $\mathrm{L}^{\star}$ 값은 lightness를, $\mathrm{a}^{*}$ 와 $-\mathrm{a}^{*}$ 값은 redness와 greenness를, $\mathrm{b}^{*}$ 와 $-\mathrm{b}^{*}$ 값은 yellowness와 blueness를 각각 나타낸다. $\mathrm{h}^{\circ}$ 값은 색상(red-purple: $0^{\circ}$, yellow: $90^{\circ}$, bluish-green: $180^{\circ}$, blue: $270^{\circ}$ )을 나타내고, $a>0$, $\mathrm{b}>0$ 이면 $\mathrm{h}^{\circ}=\tan ^{-1}(\mathrm{~b} / \mathrm{a})$ 로, $\mathrm{a}<0, \mathrm{~b}>0$ 이면 $\mathrm{h}^{\circ}=180^{\circ}+\tan ^{-1}(\mathrm{~b} / \mathrm{a})$ 으로 각각 계산된다. $\mathrm{C}^{*}$ 값은 채도를 나타내고, $\mathrm{C}^{*}=\left(\mathrm{a}^{* 2}+\mathrm{b}^{* 2}\right) 1 / 2$ 로 계산된다.

\section{가용성 고형분 함량 측정}

유자껍질 티백 침출차의 가용성 고형분 함량은 휴대용 굴절계(Master-a, Atago Co., Tokyo, Japan)를 사용하여 측정 하였다.

\section{적정산도 및 $\mathrm{pH}$ 측정}

유자껍질 티백 침출차의 적정산도는 시료액 $25 \mathrm{~mL}$ 취하 고 $0.01 \mathrm{~N} \mathrm{NaOH}$ 용액으로 $\mathrm{pH} 8.2$ 가 될 때까지 적정하여 소비된 $\mathrm{mL}$ 수를 citric acid로 환산하여 나타내었다. $\mathrm{pH}$ 는 $\mathrm{pH}$ meter(S220, Mettler-Toledo, Shanghai, China)를 사용하 여 측정하였다.

\section{유리당 함량 측정}

유자껍질 티백 침출차의 유리당 조성 및 함량은, 침출차 시료를 Waters Sep-Pak $\mathrm{C}_{18}$ cartridge에 통과시키고 $0.45 \mu \mathrm{m}$ membrane filter(Millipore Co., Bedford, MA, USA)로 여과 한 후 HPLC(600E, Waters Co., Milford, MA, USA)로 분석하 였다. 이때 유리당의 분석조건으로 컬럼은 Sugar-Pak I, 컬 럼온도는 $90^{\circ} \mathrm{C}$, 이동상은 $0.005 \% \mathrm{Ca}-\mathrm{EDTA}(0.5 \mathrm{~mL} / \mathrm{min})$, 검출기는 RI를 각각 사용하였다. 유리당의 동정 및 정량은 각 물질의 표준품을 사용하여 외부표준법으로 실시하였다.

\section{플라보노이드 함량 측정}

유자껍질 티백 침출차의 플라보노이드 함량 측정은 침출 차 시료 $0.1 \mathrm{~mL}$ 에 $99 \%$ diethylene glycol $5 \mathrm{~mL}$ 와 $4 \mathrm{~N} \mathrm{NaOH}$ $0.1 \mathrm{~mL}$ 를 가하고 $30^{\circ} \mathrm{C}$ 에서 10 분간 방치한 후 spectrophotometer (UV1800, Shimadzu, Kyoto, Japan)로 $420 \mathrm{~nm}$ 에서 흡광도를 측정하여 naringin 표준품 검량선으로 실시하였다. 


\section{$\mathrm{DPPH}$ 유리기 소거능 측정}

유자껍질 티백 침출차의 1,1-diphenyl-2-picrylhydrazyl (DPPH) radical scavenging activity는 Blois법(23)으로 측정 하였다. 즉, 시료액 $2 \mathrm{~mL}$ 에 에탄올에 용해한 $0.2 \mathrm{mmol} / \mathrm{L}$ $\mathrm{DPPH}$ 용액 $2 \mathrm{~mL}$ 가하고 10 초간 강하게 진탕하고 30 분간 정치한 후에 spectrophotometer(UV1800, Shimadzu)를 이용 하여 $517 \mathrm{~nm}$ 에서 흡광도를 측정하였다. DPPH 유리기 소거 능은 다음 식으로 계산하였다. DPPH 유리기 소거능 $(\%)=[1-($ 시료액의 흡광도/DPPH 용액의 흡광도) $\times 100]$.

\section{통계처리}

실험결과는 3회 반복실험의 평균표준편차로 나타내었 고, IBM SPSS statistics(23, IBM Corp., Armonk, NY, USA) 를 이용하여 분산분석과 Duncan's multiple range test $(\mathrm{p}<0.05)$ 를 실시하였다.

\section{결과 및 고찰}

가용성 고형분 함량, 적정산도 및 $\mathrm{pH}$ 비교

가용성 고형분 함량은 티백내 유자껍질 분말로부터 수용 성 성분의 침출 수율과 밀접한 관계에 있으며 차의 맛 결정 에 중요한 역할을 하는 것으로 알려져 있다. 건조방법을 달리한 유자껍질 티백으로 침출한 음용차의 가용성 고형분 함량은 냉풍건조구와 열풍건조구에서 각각 가장 높고 낮은 수치를 나타내었고, 냉풍건조구와 동결건조구에서는 열풍 건조구보다 약 2 배 정도 높은 함량을 나타내었다(Table 1). 한편, 건조탱자 추출물의 총당 함량도 동결건조구가 천일 건조구나 적외선건조구에 비해 높았다는 보고(24)가 있고, 건조오미자의 경우도 가용성 고형분 함량이 동결건조구가 열풍건조구 보다 높았다고 하였다(25).

건조방법을 달리한 유자껍질 티백 침출 음용차의 적정산 도는 냉풍건조구에서 유의적으로 가장 높았고 다음으로 동결건조구, 열풍건조구 순이었으나 열풍건조구는 냉풍과 동결건조구에 비해 약 $1 / 5$ 과 $1 / 8$ 정도 수준이었다(Table 1). 이로써 유자껍질의 적정산도는 열풍건조에 의해 비교적큰 폭으로 감소되는 것으로 확인되었다. 적정산도는 가용성 고형분 함량과 더불어 차의 맛에 영향을 끼치는 것으로
알려져 있으며, 적성산도를 결정하는 유자껍질에 함유된 유기산으로는 citric acid가 대부분을 차지하고 다음으로 malic acid, oxalic acid 등이 미량 존재하는 것으로 보고(26) 된 바 있다. 건조방법에 따른 유자껍질 티백 침출차의 $\mathrm{pH}$ 를 측정한 결과는(Table 1), 앞서 언급한 적정산도의 결과와 유사함을 보였으며, 열풍건조구가 가장 높고 다음으로 동 결건조구, 냉풍건조구 순이었다.

Table 1. Comparison of the soluble solid content, titratable acidity, and $\mathrm{pH}$ of hot-water leachate from teabags containing Citrus junos peel in relation to drying methods

\begin{tabular}{cccc}
\hline Drying methods & $\begin{array}{c}\text { Soluble solids } \\
\left({ }^{\circ} \text { Brix }\right)\end{array}$ & $\begin{array}{c}\text { Titratable acidity } \\
(\mathrm{mg} / 100 \mathrm{~mL})\end{array}$ & $\mathrm{pH}$ \\
\hline Hot air $\left(50^{\circ} \mathrm{C}\right)$ & $0.13 \pm 0.06^{\mathrm{b}} \mathrm{C}^{\mathrm{l}}$ & $0.43 \pm 0.10^{\mathrm{c}}$ & $4.81 \pm 0.03^{\mathrm{a}}$ \\
Cold air $\left(30^{\circ} \mathrm{C}\right)$ & $0.23 \pm 0.06^{\mathrm{a}}$ & $3.58 \pm 0.93^{\mathrm{a}}$ & $3.96 \pm 0.02^{\mathrm{c}}$ \\
Freeze $\left(-45^{\circ} \mathrm{C}\right)$ & $0.20 \pm 0.01^{\mathrm{ab}}$ & $2.39 \pm 0.10^{\mathrm{b}}$ & $4.06 \pm 0.03^{\mathrm{b}}$ \\
\hline
\end{tabular}

${ }^{1)}$ Means \pm SD (n=3) in the same column followed by same letter are not significantly different by Duncan's multiple range test $(\mathrm{p}<0.05)$.

색도 비교

건조 전 생유자껍질의 표면색도를 측정한 결과는 Table 2에 나타낸 바와 같이 $\mathrm{CIE} \mathrm{L}^{*}, \mathrm{a}^{*}, \mathrm{~b}^{*}, \mathrm{~h}^{\circ}, \mathrm{C}^{*}$ 값이 각각 68.96 , $10.77,71.55,72.51,81.41$ 이었다. 건조방법에 따른 유자껍 질 분말의 색도를 측정한 결과, 명도를 나타내는 $\mathrm{L}^{*}$ 값은 건조처리 후 증가한 경향이었으며 건조방법 간에는 동결건 조구에서 유의적으로 가장 높았고 다음으로 냉풍건조구, 열 풍건조구 순이었다(Table 2). 이는 오렌지의 경우(27)에 서와 유사하게 저온 건조가 효소적 및 비효소적 갈변반응을 억제하였기 때문인 것으로 생각된다(21). 건조 후 $\mathrm{a}^{*}$ 값은 녹색도를 나타내는 -a* 값으로 전환되었으며 그 수준은 동 결건조구에서 유의적으로 가장 높았고 다음으로 냉풍건조 구, 열풍건조구 순이었다(Table 2). 이러한 건조방법에 따른 유자껍질의 -a* 값에 대한 결과는 탱자의 경우 동결건조시 녹색색소인 chlorophyll 손실이 억제되었다는 보고(24)를 볼 때, 유자껍질에서도 같은 원인 때문인 것으로 생각된다. 황색도를 나타내는 $\mathrm{b}^{\star}$ 값은 건조 후 감소되었으며 동결과 냉풍건조구 보다 열풍건조구에서 유의적으로 낮음을 보였 다(Table 2). 이러한 유자껍질의 동결건조구에서 높은 $\mathrm{L}^{*}$

Table 2. Comparison of the color values of Citrus junos peel in relation to drying methods

\begin{tabular}{cccccc}
\hline \multirow{2}{*}{ Drying methods } & \multicolumn{5}{c}{ Color value } \\
\cline { 2 - 6 } & $\mathrm{L}^{*}$ & $\mathrm{a}^{*}$ & $\mathrm{~b}^{*}$ & $\mathrm{~h}^{\mathrm{o}}$ & $\mathrm{C}^{*}$ \\
\hline Before drying & $68.96 \pm 3.38$ & $10.77 \pm 2.65$ & $71.55 \pm 2.54$ & $72.51 \pm 2.25$ & $81.41 \pm 3.82$ \\
\hline Hot air $\left(50^{\circ} \mathrm{C}\right)$ & $77.89 \pm 0.86^{\mathrm{cl})}$ & $-0.26 \pm 0.36^{\mathrm{c}}$ & $46.98 \pm 0.50^{\mathrm{b}}$ & $90.33 \pm 0.43^{\mathrm{c}}$ & $46.99 \pm 0.50^{\mathrm{b}}$ \\
Cold air $\left(30^{\circ} \mathrm{C}\right)$ & $80.37 \pm 0.97^{\mathrm{b}}$ & $-1.91 \pm 0.69^{\mathrm{b}}$ & $49.82 \pm 0.11^{\mathrm{a}}$ & $92.20 \pm 0.80^{\mathrm{b}}$ & $49.86 \pm 0.09^{\mathrm{a}}$ \\
Freeze $\left(-45^{\circ} \mathrm{C}\right)$ & $83.08 \pm 0.70^{\mathrm{a}}$ & $-3.55 \pm 0.29^{\mathrm{a}}$ & $49.24 \pm 1.69^{\mathrm{a}}$ & $94.13 \pm 0.44^{\mathrm{a}}$ & $49.36 \pm 1.67^{\mathrm{a}}$ \\
\hline
\end{tabular}

${ }^{1)}$ Means \pm SD ( $\mathrm{n}=3$ ) in the same column followed by same letter are not significantly different by Duncan's multiple range test $(\mathrm{p}<0.05)$. 
값, $-\mathrm{a}^{*}$ 값, $\mathrm{b}^{\star}$ 값을 보인 결과는 건조탱자의 경우와 유사하였 으며(24), 오미자의 경우도 동결건조구에서 색변화가 가장 적은 것으로 알려져 있다(25). 색상을 나타내는 $\mathrm{h}^{\circ}$ 값은 건조 방법별 유의적인 차이를 보였고 열풍건조구가 yellow 정 점인 $90^{\circ}$ 에 가장 가까움을 보였고, 채도를 나타내는 $\mathrm{C}^{*}$ 값은 열풍건조구에서 유의적으로 낮은 값을 보였다(Table 2). 이상의 결과를 볼 때, 유자껍질 본래의 색 유지에는 동결건조법이 가장 유리한 것으로 확인되었다.

\section{유리당 함량 비교}

건조방법을 달리하여 제조한 유자껍질 티백 침출차의 유리당을 분석한 결과, 모든 건조구에서 유리당 함량 순위 는 fructose, glucose, sucrose 이었다(Table 3). 한편, 생유자 피의 경우도 fructose, glucose, sucrose 순인 것으로 알려져 있다(8). 건조방법에 따른 유리당 함량을 비교한 결과, sucrose 함량은 세 가지 건조법 중 동결건조구에서 유의적 으로 낮음을 보였으나 glucose와 fructose 함량은 건조방법 별 유의적인 차이를 보이지 않았다(Table 3). 건조방법에 따른 총유리당 함량 차이는 앞서 언급한 가용성 고형분의 결과와 유사하였으며, 건조방법별 그 함량은 냉풍건조구에 서 $145 \mathrm{mg} / 100 \mathrm{~mL}$, 동결건조구에서 $116 \mathrm{mg} / 100 \mathrm{~mL}$, 열풍건 조구에서 $98 \mathrm{mg} / 100 \mathrm{~mL}$ 를 나타내었다.

Table 3. Comparison of the free sugar content of hot-water leachate from teabags containing Citrus junos peel in relation to drying methods

\begin{tabular}{cccc}
\hline \multirow{2}{*}{ Drying methods } & \multicolumn{3}{c}{ Free sugar $(\mathrm{mg} / 100 \mathrm{~mL})$} \\
\cline { 2 - 4 } & Sucrose & Glucose & Fructose \\
\hline Hot air $\left(50^{\circ} \mathrm{C}\right)$ & $29.08 \pm 3.71^{\text {al })}$ & $33.08 \pm 4.09^{\mathrm{a}}$ & $35.55 \pm 4.41^{\mathrm{a}}$ \\
Cold air $\left(30^{\circ} \mathrm{C}\right)$ & $27.99 \pm 9.22^{\mathrm{a}}$ & $54.13 \pm 18.17^{\mathrm{a}}$ & $62.88 \pm 23.39^{\mathrm{a}}$ \\
Freeze $\left(-45^{\circ} \mathrm{C}\right)$ & $14.56 \pm 0.81^{\mathrm{b}}$ & $49.57 \pm 2.60^{\mathrm{a}}$ & $52.11 \pm 2.65^{\mathrm{a}}$ \\
\hline
\end{tabular}

${ }^{1)}$ Means \pm SD ( $n=3$ ) in the same column followed by same letter are not significantly different by Duncan's multiple range test $(\mathrm{p}<0.05)$.

\section{플라보노이드 함량 비교}

유자에 함유된 대표적인 플라보노이드는 naringin과 hesperidin이며 육질보다 껍질에 다량 들어있고 hesperidin 함량이 보다 높으며, 쓴맛과 다양한 생리활성 기능을 가지 며 성숙이 진행됨에 따라 감소하는 것으로 알려져 있다 $(10,28)$. 건조방법을 달리하여 제조한 유자껍질 티백 침출 차의 플라보노이드 함량은 유자껍질의 건조방법에 따른 유의적인 차이를 나타내지 않았다(Fig. 1). 이로써 건조방법 은 유자껍질의 플라보노이드 함량에 뚜렷한 영향을 미치지 않음이 확인되었다. 한편, 건조탱자의 경우에도 hesperidin 함량이 건조방법의 영향을 받지 않은 것으로 보고(24) 된 바 있다.

\section{항산화능 비교}

항산화능의 척도로 DPPH 유리기 소거능을 측정한 결과 는 냉풍건조구가 열풍건조구와 동결건조구보다 유의적으 로 높음을 보였으나 열풍건조구와 동결건조구 간에는 거의 차이를 보이지 않았다(Fig. 1). 이로써 유자껍질 티백 침출 차의 항산화능 향상에 유리한 건조방법은 냉풍건조법인 것으로 확인되었다. 이러한 유자껍질의 항산화능은 일반적 으로 페놀성 물질 및 플라보노이드 함량과 밀접한 관계를 가지는 것으로 알려져 있다(4,28).

이상의 모든 결과를 종합하면, 열풍건조법, 냉풍건조법 및 동결건조법 중 유자껍질의 본래 색 유지에는 동결건조법 이 가장 효과적인 것으로 나타났고, 냉풍건조법은 침출 음 용차의 가용성 고형분 함량, 적정산도, 유리당 함량, 항산화 능 등을 높이는 효과를 가지는 것으로 나타났다. 이러한 냉풍건조법의 적용 효과와 관련된 기작 규명에 대한 추가 연구가 필요한 것으로 사료된다.
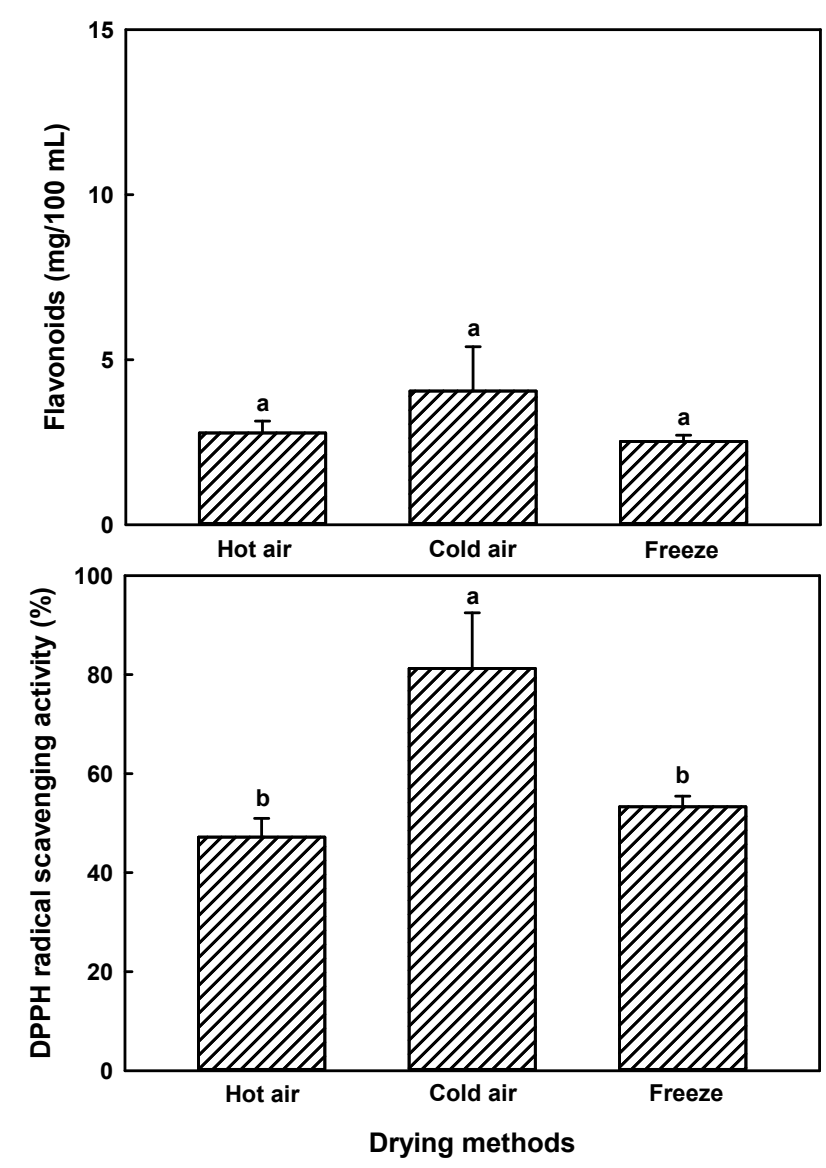

Fig. 1. Comparison of the flavonoid content and DPPH radical scavenging activity of hot-water leachate from teabags containing Citrus junos peel in relation to drying methods.

Means \pm SD ( $n=3$ ) with the different letter above the bar are significantly different by Duncan's multiple range test $(\mathrm{p}<0.05)$. 


\section{요 약}

유자껍질을 이용한 고품질 티백차를 개발하기 위하여, 생 유자껍질을 열 풍 $\left(50^{\circ} \mathrm{C}\right)$, 냉풍 $\left(30^{\circ} \mathrm{C}\right)$, 동결 $\left(-45^{\circ} \mathrm{C}\right)$ 건조한 후 분쇄하고 종이봉지로 티백 포장한 다음 열수 침출하여 얻은 음용차의 이화학적 품질특성을 조사하여 건조 방법별 비교하였다. 유자껍질 분말의 색도는 $\mathrm{L}^{*}$ 값과 -a* 값이 동결 건조구에서 유의적으로 가장 높았다. 유자껍질 티백차의 가용성 고형분 함량과 적정산도는 열풍 및 동결건조구 보다 냉풍건조구에서 보다 높은 수준을 나타내었다. 유자껍질 티백차에서 유리당은 fructose, glucose, sucrose 순으로 나타 났으며, fructose와 glucose 함량은 건조방법별 뚜렷한 차이 를 보이지 않았으나 sucrose 함량은 동결건조구에서 다소 낮음을 보였다. 플라보노이드 함량은 건조방법의 영향을 나타내지 않았으나, DPPH 유리기 소거능은 냉풍건조구에 서 유의적으로 가장 높은 수준을 보였다. 이로써, 유자껍질 을 이용한 고품질 티백차 제조시 원료의 건조방법으로 냉풍 건조법도 유효할 것으로 판단되었다.

\section{감사의 글}

이 논문은 부산대학교 기본연구지원사업(2년)에 의하여 연구되었음.

\section{References}

1. Lee YH, Na JH (2012) Citron tea exports state and quality standardization. Food Sci Ind, 45, 44-54

2. Yang JW, Jeon HL, You YH, Kim JY, Choi HK, Choi KC, Jun WJ, Yoon HG (2015) Citrus ethanol extracts promotes innate immune response by activating NF-kB. J Korean Soc Food Sci Nutr, 44, 1256-1263

3. Kim DS, Kim DH, Oh MJ, Lee KG, Kook MC, Park CS (2010) Antiaging and whitening activities of ethanol extract of Yuza (Citrus junos SIEB ex TANAKA) by-product. J Soc Cosmet Scientists Korea, 36, 137-143

4. Shin JH, Lee SJ, Seo JK, Cheon EW, Sung NJ (2008) Antioxidant activity of hot-water extract from Yuza (Citrus junos SIEB ex TANAKA) peel. J Life Sci, 18, 1745-1751

5. Kim TW, Kim KK, Kang YH, Kim DJ, Choe M (2014) Fatty acid analysis and regulatory effects of citron (Citrus junos Sieb. ex TANAKA) seed oil on nitric oxide production, lipid accumulation, and leptin secretion. J Nutr Health, 47, 221-228
6. Lee YJ, Hwang IG, Joung EM, Kim HY, Park ES, Woo KS, Jeong HS (2009) Physiological activity and antiproliferation effects of citron seed extracts on cancer cells. J Korean Soc Food Sci Nutr, 38, 1672-1678

7. Jo GS, Hwang IT, Yun BG, Suh JK (2012) Stability verification and anti-atopy efficacy on essential oil of Yuzu (Citrus junos Siebold ex Tanaka). Korean J Hort Sci Technol, 30, 58-59

8. Lee SJ, Shin JH, Kang MJ, Jeong CH, Ju JC, Sung NJ (2010) Physicochemical properties, free sugar and volatile compounds of Korean citrons cultivated in different areas. J Korean Soc Food Sci Nutr, 39, 92-98

9. Lee SJ, Chun BS (2002) Extraction of volatile essential oil from Citrus junos peel by supercritical carton dioxide. Korean J Biotechnol Bioeng, 17, 148-152

10. Kim YD, Kim KJ (2004) Optimum condition for removing bitter substance of Yuzu (Citrus junos) by enzyme treatment. Korean J Food Preserv, 11, 53-56

11. Jeong JW, Lee YC, Lee KM, Kim IH, Lee MS (1998) Manufacture condition of oleoresin using citron peel. Korean J Food Sci Technol, 30, 139-145

12. Lee JR, Jung JD, Hah YJ, Lee JI, Lee JD, Park GB, Kwak SJ (2005) Effects of addition of citron peel powder on the proximate composition, minerals, vitamin $\mathrm{A}, \mathrm{C}$ content and fatty acid composition of emulsion-type sausage. J Anim Sci Technol, 47, 99-106

13. Kim HY, Kong HJ (2006) Preparation and quality characteristics of sugar cookies using citron powder. Korean J Food Cookery Sci, 23, 712-719

14. Jin TY, Wang MH, Yin Y, Eun JB (2008) Effect of Citrus junos peel on the quality and antioxidant activity of traditional rice wine, Jinyangju. J Korean Soc Food Sci Nutr, 37, 76-82

15. Yang HS, Hwang SJ, Lee SH, Eun JB (2011) Fermentation characteristics and sensory characteristics of Makgeolli with dried citron (Citrus junos SIEB ex TANAKA) peel. Korean J Food Sci Technol, 43, 603-610

16. Chung HS, Youn KS, Seong JH, Moon KD (2007) Quality properties of tea extracts prepared with persimmon flowers. Korean J Food Preserv, 14, 148-153

17. Jang MJ, Ha HJ, Yoon SR, Noh JE, Kwon JH (2006) Prediction of optimal leaching conditions for green tea. J Korean Soc Food Sci Nutr, 35, 747-753

18. Kim JW, Lee SH, No HK, Hong JH, Park CS, Youn KS (2013) Effects of pretreatment and drying methods on quality and antioxidant activities of dried jujube (Zizyphus jujuba) fruit. J Korean Soc Food Sic Nutr, 
42, $1242-1248$

19. Chung HS, Youn KS (2005) Effects of microwave, ultrasound and roasting pretreatments on hot water extraction of Acanthopanax senticosus. Korean J Food Preserv, 12, 146-150

20. Kim JH, Choi MS, Moon KD (2000) Quality characteristic of drink and tea-bag processed with safflower seed powder. Korean J Postharvest Sci Technol, 7, 171-176

21. Krokida M, Maroulis Z (2000) Quality changes during drying of food materials. In : Drying technology in agriculture and food sciences, Mujumdar AS (Editor), Science publishers, Inc., Plymouth, UK, p 61-106

22. Ji EJ, Yoo KM, Park JB, Hwang IK (2008) Preparation of citron peel tea containing Yuza (Citrus junos Seib ex TANAKA) and its antioxidant characteristics. Korean J Food Cookery Sci, 24, 460-465

23. Blois MS (1958) Antioxidant determination by the use of a stable free radical. Nature, 181, 1199-1200
24. Chung HS, Hwang SH, Youn KS (2005) Physicochemical characteristics of Ponciri fructus in relation to drying treatment. Korean J Food Preserv, 12, 449-454

25. Lee S, Moon HK, Lee SW, Moon JN, Kim JK (2014) Effects of drying methods on quality characteristics and antioxidative effects of Omija (Schizandra chinesis bailon). Korean J Food Preserv, 21, 341-349

26. Hwang SH, Kim MJ, Kim KS (2013) Biochemical properties, volatile compounds and total phenol contents of Yuza variety. Korean J Food Nutr, 26, 685-692

27. Barbosa J, Borges S, Amorim M, Pereira MJ, Oliveira A, Pintado ME, Teixeira P (2015) Comparison of spray drying, freeze drying and convective hot air drying for the production of a probiotic orange powder. J Functional Foods, 17, 340-351

28. Moon SH, Assefa AD, Ko EY, Park SW (2015) Comparison of flavonoid contents and antioxidant activity of Yuzu (Citrus junos Sieb. ex Tanaka) based on harvest time. Korean J Hort Sci Technol, 33, 283-291 